\title{
Effect of Cotreatment with Corticosteroids in \\ Connective Tissue Related Lung Disease (CTD-ILD) Patients on Mycophenolate Mofetil (MMF)
}

Roberto Caricchio

Temple University

Erin R Narewski ( $\square$ Erin.Narewski@tuhs.temple.edu )

Temple University

Ryan Townsend

Temple University Hospital

Stephen Codella

Temple University Hospital

Jin Sun Kim

Temple University Hospital

Ashwin Karanam

Temple University Hospital

Joseph A Ramzy

Temple University Hospital

Simona Levsky

Temple University

Huaqing Zhao

Temple University

Gerard Criner

Temple University

\section{Research Article}

Keywords: Connective Tissue Related Lung Disease (CTD-ILD), Mycophenolate Mofetil (MMF), Corticosteroids

Posted Date: February 18th, 2021

DOI: https://doi.org/10.21203/rs.3.rs-208857/v1

License: (a) (i) This work is licensed under a Creative Commons Attribution 4.0 International License.

Read Full License 


\section{Abstract}

Introduction: Connective Tissue Disease Related Interstitial Lung Disease (CTD-ILD) is often treated with immunosuppressant medications; common among these is Mycophenolate Mofetil (MMF). We hypothesized that co-treatment with corticosteroids would impact disease progression.

Methods: We examined a consecutive cohort of CTD-ILD patients followed at Temple University Hospital in Philadelphia, PA since 2015 who had pulmonary function tests (PFTs) performed by American Thoracic Society (ATS)/European Respiratory Society (ERS) Criteria at least one year apart. All patients were treated for CTD-ILD with MMF used either as sole therapy or as combination therapy with prednisone. Univariate logistic analyses were performed revealing the odds ratio (OR) for improvement or worsening of several PFT values (including forced vital capacity (FVC), diffusion capacity of carbon monoxide $\left(\mathrm{DL}_{\mathrm{CO}}\right)$, and six-minute walk $(6 \mathrm{MW})$ ) greater than the minimal clinically important difference (MCID) for each value.

Results: We included 103 patients ( 74 women) with an average age of $60 \pm 11$ years, $49 \%$ of our cohort were current or former smokers, and mean BMI was $29 \pm 7 \mathrm{~kg} / \mathrm{m}^{2}$. Patients were observed on treatment for an average of 23 months. CTD distribution included 25\% mixed connective tissue disease (MCTD), $24 \%$ systemic sclerosis (SSc), $17 \%$ rheumatoid arthritis (RA), $14 \%$ systemic lupus erythematosus (SLE), $10 \%$ other idiopathic inflammatory myositis (IIM) syndromes, $7 \%$ Antisynthetase Syndrome, 5\% Sjögren's syndrome. Non-specific interstitial pneumonia (NSIP) was the majority (45\%) ILD pattern noted, Usual Interstitial Pneumonia (UIP) 35\%, and other types were less prevalent (20\%). The majority of patients received corticosteroids as co-treatment with MMF (75 patients $(72 \%)$ ) with a mean daily dose of $15 \pm 16$ $\mathrm{mg}$ of prednisone. Mean daily MMF dose was $1144 \pm 675 \mathrm{mg}$. Glucocorticoid treatment was not associated with significant improvements in PFT values, including $\mathrm{FVC}, \mathrm{DL}_{\mathrm{CO}}$, and $6 \mathrm{MW}$ distance walked.

Conclusion: In this small cohort, patients with CTD-ILD receiving MMF did not demonstrate improved lung function when receiving co-treatment with corticosteroids, but larger prospective studies are needed to better elucidate the effect of corticosteroids on this vulnerable group of patients.

\section{Introduction}

Connective tissue disease-related interstitial lung disease (CTD-ILD) is a form of interstitial lung disease (ILD) common to patients with connective tissue diseases (CTD) including systemic sclerosis (SSc), rheumatoid arthritis (RA), idiopathic inflammatory myositis (IIM) syndromes, Sjögren's syndrome, mixed connective tissue disease (MCTD), and other forms of CTD. ${ }^{1,2}$ Although ILD is associated with high rates of morbidity and mortality in CTD patients, compared to patients with idiopathic interstitial pneumonias a CTD-ILD diagnosis conveys survival benefit and a potential for symptomatic improvement with immunomodulator therapy. ${ }^{1-5}$ 
Medications commonly used in CTD-ILD include mycophenolate mofetil (MMF), Tacrolimus, Cyclophosphamide, Azathioprine, Rituximab, and corticosteroids. ${ }^{4}$ MMF is increasingly used in CTD-ILD and has been found in retrospective analyses to be well tolerated, to have a low rate of discontinuation, to be associated with lower concomitant daily corticosteroid doses, and with stabilization or improvement in forced vital capacity (FVC) and diffusion capacity for carbon monoxide $\left(\mathrm{DL}_{\mathrm{CO}}\right) \cdot{ }^{6-11}$ CTD-ILD patients benefit from few published randomized controlled trials. ${ }^{10,12}$

Corticosteroids are often used as co-management with other therapies in CTD-ILD patients. Because clinical trials have focused mainly on SSc-ILD patients, there has been a limited role for corticosteroids at doses $>15 \mathrm{mg} / \mathrm{d}$ of prednisone due to the risk of renal crisis. For broader populations, corticosteroid use in CTD-ILD has not been studied in detail. ${ }^{13,14}$ Yamano et al. (2018) evaluated high dose methylprednisolone followed by low dose prednisone and Tacrolimus in a population of 26 CTD-ILD patients, a protocol which produced improvements, ${ }^{15}$ but to our knowledge no other research has evaluated the benefit of corticosteroids in patients taking other therapies.

We hypothesized that patients taking MMF for CTD-ILD would gain a small benefit from co-treatment with corticosteroids.

\section{Methods}

After approval by the Temple University Institutional Review Board, we retrospectively analysed a consecutive cohort of CTD-ILD patients prescribed MMF. Each patient had a diagnosis of CTD per American College of Rheumatology (ACR) classification criteria by a board-certified rheumatologist and had ILD confirmed by high-resolution CT chest (HRCT) or by histology. Each patient also had pulmonary function tests including spirometry, diffusion capacity for carbon monoxide $\left(\mathrm{DL}_{\mathrm{CO}}\right)$, and six-minute walk $(6 \mathrm{MW})$.

Each patient was followed continuously at Temple University Hospital (Philadelphia, PA) for an average of 23 months between January 1, 2015 and January 1, 2019, with Pulmonary Function Tests (PFTs) performed according to American Thoracic Society (ATS)/European Respiratory Society (ERS) Criteria measured at least one year apart. ${ }^{16}$ We excluded patients with inadequate PFTs $(n=52)$, those who did not meet ACR classification criteria for a specific CTD $(n=82)$, those who did not have ILD by review of HRCT of chest or by histology $(n=51)$, those who were followed for less than 26 weeks $(n=11)$, those who received a lung transplant $(n=9)$, or those with physician-documented MMF nonadherence $(n=5)$ (Fig. 1).

103 subjects met the above inclusion and exclusion criteria. The following data were extracted from the medical record for each subject: demographics including age, gender, body mass index (BMI), race, ethnicity, and smoking status, pattern of ILD by HRCT or histology, baseline autoantibodies tested, rheumatologic diagnosis by ACR criteria, systemic manifestations of CTD as documented by a board- 
certified rheumatologist, and treatment dose and duration for both MMF and corticosteroids (Figs. 2,3; Table 1). 
Table 1

Demographic Data of CTD-ILD Patients at Time of MMF Treatment Initiation

\begin{tabular}{|c|c|c|c|c|}
\hline & $\begin{array}{l}\text { Entire } \\
\text { Cohort }\end{array}$ & $\begin{array}{l}\text { MMF } \\
\text { Only }\end{array}$ & $\begin{array}{l}\text { Cotreatment with } \\
\text { Corticosteroids }\end{array}$ & $\begin{array}{l}\mathrm{p}- \\
\text { value }\end{array}$ \\
\hline $\mathrm{N}$ & 103 & 28 & 75 & \\
\hline Age (Years), Mean ( \pm SD) & $\begin{array}{l}60.1 \pm \\
13\end{array}$ & $\begin{array}{l}60.6 \pm \\
12.4\end{array}$ & $60.0 \pm 11.8$ & 0.82 \\
\hline Male (n), (\%) & $\begin{array}{l}29 \\
(28 \%)\end{array}$ & $\begin{array}{l}10 \\
(35 \%)\end{array}$ & $19(25 \%)$ & 0.30 \\
\hline Current or Former Smoking (n), (\%) & $\begin{array}{l}51 \\
(49 \%)\end{array}$ & $\begin{array}{l}12 \\
(42 \%)\end{array}$ & $39(52 \%)$ & 0.41 \\
\hline BMI (Mean), ( \pm SD) & $\begin{array}{l}29.7 \pm \\
7.1\end{array}$ & $\begin{array}{l}28.3 \pm \\
6.8\end{array}$ & $30.3 \pm 7.2$ & 0.20 \\
\hline \multicolumn{5}{|l|}{ Race } \\
\hline Caucasian (n), (\%) & $\begin{array}{l}53 \\
(52 \%)\end{array}$ & $\begin{array}{l}13 \\
(48 \%)\end{array}$ & $40(54 \%)$ & \multirow[t]{4}{*}{0.41} \\
\hline African American (n), (\%) & $\begin{array}{l}31 \\
(31 \%)\end{array}$ & $\begin{array}{l}11 \\
(43 \%)\end{array}$ & $20(27 \%)$ & \\
\hline Asian (n), (\%) & $2(2 \%)$ & $1(1 \%)$ & $1(4 \%)$ & \\
\hline Other $(n),(\%)$ & $\begin{array}{l}15 \\
(15 \%)\end{array}$ & $2(7 \%)$ & $13(18 \%)$ & \\
\hline \multicolumn{5}{|l|}{ Ethnicity } \\
\hline Hispanic / Latin American & $\begin{array}{l}15 \\
(15 \%)\end{array}$ & $2(7 \%)$ & $13(17 \%)$ & 0.35 \\
\hline \multicolumn{5}{|l|}{ Rheumatologic Disease by ACR Criteria } \\
\hline $\operatorname{MCTD}(n),(\%)$ & $\begin{array}{l}26 \\
(25 \%)\end{array}$ & $\begin{array}{l}3 \\
(11 \%)\end{array}$ & $23(31 \%)$ & 0.04 \\
\hline Systemic Sclerosis (n), (\%) & $\begin{array}{l}25 \\
(24 \%)\end{array}$ & $\begin{array}{l}8 \\
(29 \%)\end{array}$ & $14(19 \%)$ & 0.24 \\
\hline RA (n), (\%) & $\begin{array}{l}18 \\
(17 \%)\end{array}$ & $1(4 \%)$ & $17(23 \%)$ & 0.02 \\
\hline SLE (n), (\%) & $\begin{array}{l}15 \\
(14 \%)\end{array}$ & $\begin{array}{l}5 \\
(18 \%)\end{array}$ & $10(13 \%)$ & 0.56 \\
\hline Antisynthetase Syndrome (n), (\%) & $7(7 \%)$ & $6(8 \%)$ & $1(4 \%)$ & 0.43 \\
\hline \multicolumn{5}{|c|}{$\begin{array}{l}\text { Legend: Connective Tissue Disease-Associated Interstitial Lung Disease (CTD-ILD), Mycophenolate } \\
\text { Mofetil (MMF), American College of Rheumatology (ACR), Connective Tissue Disease (CTD), } \\
\text { Standard Deviation (SD), Mixed Connective Tissue Disease (MCTD), Rheumatoid Arthritis (RA), } \\
\text { Systemic Lupus Erythematosus (SLE), milligrams (mg) }\end{array}$} \\
\hline
\end{tabular}




\begin{tabular}{|c|c|c|c|c|}
\hline & $\begin{array}{l}\text { Entire } \\
\text { Cohort }\end{array}$ & $\begin{array}{l}\text { MMF } \\
\text { Only }\end{array}$ & $\begin{array}{l}\text { Cotreatment with } \\
\text { Corticosteroids }\end{array}$ & $\begin{array}{l}\mathrm{p}- \\
\text { value }\end{array}$ \\
\hline $\begin{array}{l}\text { Other Idiopathic Inflammatory Myositis (n), } \\
(\%)\end{array}$ & $\begin{array}{l}10 \\
(10 \%)\end{array}$ & $\begin{array}{l}3 \\
(11 \%)\end{array}$ & $7(9 \%)$ & 0.83 \\
\hline Sjögren's Syndrome $(n),(\%)$ & $5(5 \%)$ & $2(7 \%)$ & $3(4 \%)$ & 0.51 \\
\hline \multicolumn{5}{|l|}{ Systemic Manifestations of CTD } \\
\hline Arthropathy (n), (\%) & $\begin{array}{l}36 \\
(43 \%)\end{array}$ & $\begin{array}{l}10 \\
(36 \%)\end{array}$ & $47(63 \%)$ & 0.01 \\
\hline Mucocutaneous (n), (\%) & $\begin{array}{l}27 \\
(40 \%)\end{array}$ & $\begin{array}{l}11 \\
(39 \%)\end{array}$ & $24(32 \%)$ & 0.49 \\
\hline Pulmonary Hypertension, n (\%) & $\begin{array}{l}39 \\
(37 \%)\end{array}$ & $\begin{array}{l}10 \\
(36 \%)\end{array}$ & $29(39 \%)$ & 0.76 \\
\hline Raynaud Phenomenon (n), (\%) & $\begin{array}{l}20 \\
(29 \%)\end{array}$ & $\begin{array}{l}9 \\
(32 \%)\end{array}$ & $23(31 \%)$ & 0.89 \\
\hline Myalgia or Myositis (n), (\%) & $\begin{array}{l}13 \\
(19 \%)\end{array}$ & $\begin{array}{l}4 \\
(14 \%)\end{array}$ & $13(17 \%)$ & 0.71 \\
\hline Nephropathy (n), (\%) & $2(2 \%)$ & $0(0 \%)$ & $4(5.3 \%)$ & 0.21 \\
\hline \multicolumn{5}{|l|}{ Treatment } \\
\hline $\begin{array}{l}\text { MMF Dose, Beginning of Observation Period } \\
\text { (mg/day) Mean }( \pm \text { SD) }\end{array}$ & $\begin{array}{l}1144 \pm \\
657\end{array}$ & $\begin{array}{l}1539 \\
\pm 926\end{array}$ & $1007 \pm 469$ & 0.009 \\
\hline $\begin{array}{l}\text { MMF Dose, End of Observation Period } \\
(\mathrm{mg} / \text { day) Mean }( \pm \mathrm{SD})\end{array}$ & $\begin{array}{l}2144 \pm \\
835\end{array}$ & $\begin{array}{l}2055 \\
\pm 742\end{array}$ & $2176 \pm 870$ & 0.51 \\
\hline Co-treatment with Corticosteroids (n), (\%) & $\begin{array}{l}75 \\
(72 \%)\end{array}$ & $0(0 \%)$ & 75 (100\%) & $\begin{array}{l}<.001 \\
0.01\end{array}$ \\
\hline Co-treatment with PH Therapy (n), (\%) & $\begin{array}{l}14 \\
(14 \%)\end{array}$ & $\begin{array}{l}5 \\
(17 \%)\end{array}$ & $9(12 \%)$ & 0.33 \\
\hline Co-treatment with PH Triple Therapy (N), (\%) & $5(5 \%)$ & $2(7 \%)$ & $3(4 \%)$ & 0.48 \\
\hline Co-treatment with Antifibrotic (N), (\%) & $9(9 \%)$ & $\begin{array}{l}4 \\
(14 \%)\end{array}$ & $5(7 \%)$ & 0.22 \\
\hline \multicolumn{5}{|c|}{$\begin{array}{l}\text { Legend: Connective Tissue Disease-Associated Interstitial Lung Disease (CTD-ILD), Mycophenolate } \\
\text { Mofetil (MMF), American College of Rheumatology (ACR), Connective Tissue Disease (CTD), } \\
\text { Standard Deviation (SD), Mixed Connective Tissue Disease (MCTD), Rheumatoid Arthritis (RA), } \\
\text { Systemic Lupus Erythematosus (SLE), milligrams (mg) }\end{array}$} \\
\hline
\end{tabular}

Patients were then divided into two groups, those who received only MMF, and those who received MMF and a corticosteroid. Chi-squared or paired t-tests were used to compare demographic and baseline data 
between the two groups, and to describe the change in PFT values and medication doses over time in the entire cohort (Table 1,2).

Table 2

Pulmonary Function Tests, Exercise Capacity, Oxygen Requirement, and Corticosteroid Dose Over 23 Months of Observation on MMF, Entire Cohort

\begin{tabular}{|c|c|c|c|c|}
\hline \multirow[b]{2}{*}{ FVC (L), (Mean $\pm S D)$} & \multirow{2}{*}{$\begin{array}{l}\mathbf{N} \\
96\end{array}$} & \multicolumn{2}{|c|}{$\begin{array}{l}\text { Observation Period } \\
\text { Start Finish }\end{array}$} & \multirow{2}{*}{$\begin{array}{l}\mathbf{P} \\
\text { Value } \\
0.07\end{array}$} \\
\hline & & $\begin{array}{l}2.05 \pm \\
0.63\end{array}$ & $\begin{array}{l}1.98 \pm \\
0.71\end{array}$ & \\
\hline FVC \% Predicted, (Mean \pm SD) & 98 & $63 \pm 16$ & $62 \pm 19$ & 0.21 \\
\hline DLCO (ml/min/mmHg), (Mean \pm SD) & 77 & $10.2 \pm 5.2$ & $8.5 \pm 3.6$ & 0.01 \\
\hline $\mathrm{DL}_{\mathrm{CO}} \%$ Predicted, (Mean $\pm \mathrm{SD}$ ) & 76 & $39 \pm 16$ & $35 \pm 15$ & 0.01 \\
\hline 6MW Distance (meters), (Mean \pm SD) & 79 & $\begin{array}{l}272 \pm \\
116\end{array}$ & $277 \pm$ & 0.61 \\
\hline $\begin{array}{l}\text { Oxygen Required On Exercise During 6MW (L/min), } \\
\text { (Mean } \pm \text { SD) }\end{array}$ & 80 & $2.7 \pm 3.4$ & $2.7 \pm 4.0$ & 0.35 \\
\hline Corticosteroid Dose (mg prednisone), (Mean \pm SD) & 103 & $\begin{array}{l}15.7 \pm \\
18.6\end{array}$ & $7.9 \pm 9.1$ & ¿. 001 \\
\hline MMF Dose (mg/day), (Mean \pm SD) & 101 & $\begin{array}{l}1275 \pm \\
827\end{array}$ & $\begin{array}{l}2143 \pm \\
835\end{array}$ & $\hat{0} .001$ \\
\hline \multicolumn{5}{|c|}{$\begin{array}{l}\text { Legend: Mycophenolate Mofetil (MMF), Forced Vital Capacity (FVC), Liters (L), Standard Deviation } \\
\left.\text { (SD), Diffusion Capacity of Carbon Monoxide (DL } \mathrm{C}_{\mathrm{Co}}\right) \text {, Milliliters }(\mathrm{ml}) \text {, Minute (min), Millimeters of } \\
\text { Mercury (mmHg), Percent (\%), Six Minute Walk (6MW), Milligrams (mg) }\end{array}$} \\
\hline
\end{tabular}

Univariate logistic analyses were then performed revealing the odds ratio (OR) for improvement or worsening of several PFT values between the two groups (including forced vital capacity $(F V C), D_{C O}$, and $6 \mathrm{MW}$ distance greater than the minimal clinically important difference (MCID) for each value. Given the small number of patients in the study, improvement of $\mathrm{FVC}, \mathrm{DL}_{\mathrm{CO}}$, and/or $6 \mathrm{MW}$ distance greater than the MCID for each test was analysed as a combined variable. Data are presented as percent (\%), mean \pm standard deviation (SD) or $\mathrm{OR} \pm$ confidence interval. P-values $<0.05$ were considered statistically significant.

\section{Results}

We included 103 patients who were observed on treatment with MMF for an average of 23 months. The baseline characteristics of the 103 consecutive patients are summarized in Table 1 and compared between groups. Patients were predominantly female had an average age of $60 \pm 11$ years, a mean BMI 
of $29 \pm 7$, and $49 \%$ were current or former smokers. The racial breakdown of our cohort was $52 \%$ Caucasian, $31 \%$ African American, $2 \%$ Asian, and $15 \%$ other race or mixed race. $15 \%$ of patients identified as being of hispanic ethnicity (Table 1).

The distribution of CTD in the patient cohort was 25\% MCTD, 24\% SSc, 17\% RA, $14 \%$ systemic lupus erythematosus (SLE), $10 \%$ other IIM syndromes, $7 \%$ Antisynthetase Syndrome, 5\% Sjögren's syndrome. The baseline autoantibodies found to be positive according to standard laboratory reference ranges in our patient cohort are summarized in Fig. 3, with a majority (52.4\%) having Antinuclear Antibodies (ANA), which was defined as "positive" at titre $\geq 1: 320,34 \%$ Rheumatoid Factor (RF), 15.5\% Sjögren's SyndromeRelated-Antigen A/Anti-Rho (SS-A), and the remainder having other antibodies (Sjögren's SyndromeRelated-Antigen B/Anti-La (SS-B), citric citrullinated peptide (CCP), anti-Jo1, Anti-Smith, etc.)

Clinical manifestations of CTD in this cohort included arthropathy (43\%), mucocutaneous disease (40\%), pulmonary hypertension (37\%), Raynaud Phenomenon (29\%), myalgia or myositis (19\%), and nephropathy $(2 \%)$ (Table 1$)$.

$45 \%$ of patients had a non-specific interstitial pneumonia (NSIP) pattern noted on HRCT, $35 \%$ had a usual interstitial pneumonia (UIP) pattern, and the remainder (20\%) had other ILD patterns including bronchiolitis, mixed patterns, and organizing pneumonia (Fig. 2).

The majority of patients $(n=75,72 \%)$ received corticosteroids as co-treatment with MMF, and the remainder received MMF as sole therapy $(n=28,28 \%)$. Overall, patients received a mean daily dose of 15 $\pm 16 \mathrm{mg}$ of prednisone and mean daily MMF dose of $2000 \mathrm{mg}$. Additionally, 14 patients (14\%) received pulmonary hypertension $(\mathrm{PH})$ cotreatment. Only 5 of these patients $(5 \%)$ received three concurrently prescribed $\mathrm{PH}$ medications. 9 patients $(9 \%)$ received cotreatment with an antifibrotic (Table 1).

Significant differences were noted between patients receiving MMF as sole therapy when compared to patients receiving corticosteroids as co-treatment with MMF. Patients receiving co-treatment with corticosteroids were more likely to have diagnoses of RA or MCTD, were more likely to report arthropathy, and received lower starting doses of MMF (1007 \pm 469 milligrams (mg) per day vs $1539 \pm 926 \mathrm{mg} /$ day ( $p$ $=0.009)$ (Table 1).

For the entire cohort, decreases were noted in mean $\mathrm{FVC}$, mean $\mathrm{DL}_{\mathrm{CO}}$, and mean $\mathrm{DL}_{\mathrm{CO}} \%$ predicted over the follow-up interval, but ambulatory oxygen requirement in liters/minute via nasal cannula and distance walked on $6 \mathrm{MW}$ testing did not change significantly. The mean prescribed prednisone dose decreased significantly $(p<0.001)$ from 15.7 to $7.9 \mathrm{mg}$ and the mean MMF dose increased significantly $(p<0.001)$ from 1275 to $2143 \mathrm{mg} /$ day over the course of the study period (Table 2).

We hypothesized that patients taking MMF for CTD-ILD would gain a small benefit from cotreatment with corticosteroids. There were no significant differences in changes in PFT values between those treated with corticosteroids in addition to MMF versus those treated only with MMF. Over the observation period, 
pulmonary physiology, but suggests a discrepancy between physiological effects and overall clinical significance to patients. These findings highlight the need for further study to better correlate effects on pulmonary physiology to functional status and overall quality of life.

This study had several limitations. Our cohort of only 103 patients was small and recruited from a single center. However, this cohort is valuable for study, as most research on CTD-ILD patients thus far includes a large number of patients with systemic sclerosis. ${ }^{6,9,12}$ Our cohort had a diverse distribution of CTD and may be more representative of the diversity of disease encountered in clinical practice outside of systemic sclerosis specialty centers. Larger studies across multiple treatment centers are needed to avoid confounding variables and to increase confidence in the results. Our cohort was recruited at a specialty lung center, which may confer referral bias.

As there are no guidelines for corticosteroid treatment in patients with CTD-ILD, more research is needed to elucidate the optimal dosing and duration of therapy, and to clarify the goals of therapy. It remains unclear whether the addition of corticosteroids to steroid-sparing therapy benefits patients with CTD-ILD, and if so, in which subgroups and to what degree. Our patients received a minimum of 26 weeks and average of 23 months of follow-up. Longer term analyses may further uncover corticosteroid side effects which may affect their long-term tolerability.

\section{Conclusion}

In this small cohort, patients with CTD-ILD receiving treatment with MMF did not demonstrate improved lung function when receiving co-treatment with corticosteroids. Larger prospective studies are needed to better elucidate the effect of corticosteroids on this vulnerable group of patients.

\section{Abbreviations List}

ACR American College of Rheumatology

ADL Activities of Daily Living

ATS American Thoracic Society

BMI Body Mass Index

CTD-ILD Connective Tissue Disease Related Interstitial Lung Disease

$\mathrm{DL}_{\mathrm{CO}}$ Diffusing Capacity of the lung for Carbon Monoxide

ERS European Respiratory Society

FVC Forced Vital Capacity

HRCT High Resolution Computed Tomography 
IIM Idiopathic Inflammatory Myositis

ILD Interstitial Lung Disease

MCID Minimal Clinically Important Difference

MCTD Mixed Connective Tissue Disease

MMF Mycophenolate Mofetil

NSIP Non-Specific Interstitial Pneumonia

PH Pulmonary Hypertension

SScSystemic Sclerosis

SSc-ILD Systemic Sclerosis-related ILD

UIP Usual Interstitial Pneumonia

6MWD 6-Minute Walking Distance

\section{Declarations}

This research was conducted after IRB approval and was deemed exempt from ethics committee approval by Temple University, and in compliance with all relevant guidelines and regulations.

The datasets used and/or analyzed during the current study are available from the corresponding author on reasonable request.

\section{Acknowledgements:}

J.R. and E.N. conceived of the presented idea. J.R., R.T., S.C., J.S.K., A.K., and E.N. collected and processed experimental data. J.R., E.N., and H.Z. performed the analysis and verified the statistical methods. G.C., R.C., and E.N aided in interpreting the results. S.L., E.N., and R.C. wrote and edited the manuscript. All authors contributed input to the manuscript, discussed the results, and contributed meaningfully to the project.

All authors consent to the publication of the manuscript and have approved the submitted version. All authors have agreed both to be personally accountable for the author's own contributions and to ensure that questions related to the accuracy or integrity of any part of the work, even ones in which the author was not personally involved, are appropriately investigated, resolved, and the resolution documented in the literature.

Consent for Publication: Not applicable 
Informed Consent: This study was deemed exempt from informed consent requirements as patient data were deidentified immediately after extraction and held securely. The Temple University Institutional Review Board approved this exemption from informed consent and the study data were deidentified and secured according to institutional protocols for exempt research.

Conflict of Interest Statements: All authors declare that they have no competing interests.

Joseph A Ramzy MD: No conflicts of interests exist for this author.

Simona Levsky MS-4: No conflicts of interests exist for this author.

Ryan Townsend, MD: No conflicts of interests exist for this author.

Stephen Codella, MD: No conflicts of interests exist for this author.

Jin Sun Kim, MD: No conflicts of interests exist for this author.

Ashwin Karanam, MD: No conflicts of interests exist for this author.

Huaqing Zhao, PhD: No conflicts of interests exist for this author.

Gerard Criner MD, FCCP, ATSF: No conflicts of interests exist for this author.

Roberto Caricchio, MD, FACR: No conflicts of interests exist for this author.

Erin Narewski, DO FCCP, : No conflicts of interests exist for this author.

Funding information: None, this research received no funding.

Notation of prior abstract publication/presentation:

Some of these data were presented in abstract form at the 2019 American Thoracic Society International Conference.

\section{References}

1. Vij R, Strek ME. Diagnosis and treatment of connective tissue disease-associated interstitial lung disease. Chest. 2013;143(3):814-824. https://search.datacite.org/works/10.1378/chest.12-0741. doi: 10.1378/chest.12-0741.

2. Park JH, Kim DS, Park I-, et al. Prognosis of fibrotic interstitial pneumonia: Idiopathic versus collagen vascular disease-related subtypes. Am J Respir Crit Care Med. 2007;175(7):705-711. Accessed Jul 22, 2020. doi: 10.1164/rccm.200607-9120C. 
3. Olson AL, Swigris JJ, Sprunger DB, et al. Rheumatoid Arthritis-Interstitial lung disease-associated mortality. Am J Respir Crit Care Med. 2011;183(3):372-378.

https://www.ncbi.nlm.nih.gov/pmc/articles/PMC5450769/. Accessed Jul 22, 2020. doi: 10.1164/rccm.201004-06220C.

4. Bongartz T, Nannini C, Medina-Velasquez YF, et al. Incidence and mortality of interstitial lung disease in rheumatoid arthritis: A population based study. Arthritis Rheum. 2010;62(6):1583-1591. https://www.ncbi.nlm.nih.gov/pmc/articles/PMC4028137/. Accessed Jul 22, 2020. doi: 10.1002/art.27405.

5. Vij R, Noth I, Strek ME. Autoimmune-featured interstitial lung disease: A distinct entity. Chest. 2011;140(5):1292-1299. Accessed Jul 23, 2020. doi: 10.1378/chest.10-2662.

6. Fischer DA, Brown KK, Bois RMD, et al. Mycophenolate mofetil improves lung function in connective tissue disease-associated interstitial lung disease. The Journal of rheumatology. 2013;40(5):640. https://www-ncbi-nlm-nih-gov.libproxy.temple.edu/pmc/articles/PMC3676865/. Accessed Jul 21, 2020. doi: 10.3899/jrheum.121043.

7. Gerbino AJ, Goss CH, Molitor JA. Effect of mycophenolate mofetil on pulmonary function in scleroderma-associated interstitial lung disease. Chest. 2008;133(2):455-460. Accessed Jul 22, 2020. doi: 10.1378/chest.06-2861.

8. Zamora AC, Wolters PJ, Collard HR, et al. Use of mycophenolate mofetil to treat sclerodermaassociated interstitial lung disease. Respir Med. 2008;102(1):150-155. Accessed Jul 22, 2020. doi: 10.1016/j.rmed.2007.07.021.

9. Dp T, Md R, Pj C, et al. Mycophenolate mofetil versus oral cyclophosphamide in scleroderma-related interstitial lung disease (SLS II): A randomised controlled, double-blind, parallel group trial. The Lancet. Respiratory medicine Web site. https://pubmed-ncbi-nlm-nihgov.libproxy.temple.edu/27469583/?dopt=Abstract. Updated 2016. Accessed Jul 21, 2020.

10. Tashkin PDP, Roth PMD, Clements PPJ, et al. Mycophenolate mofetil versus oral cyclophosphamide in scleroderma-related interstitial lung disease: Scleroderma lung study II (SLS-II), a double-blind, parallel group, randomised controlled trial. The Lancet. Respiratory medicine. 2016;4(9):708. https://www-ncbi-nlm-nih-gov.libproxy.temple.edu/pmc/articles/PMC5014629/. Accessed Jul 21, 2020. doi: 10.1016/S2213-2600(16)30152-7.

11. Swigris JJ, Olson AL, Fischer A, et al. Mycophenolate mofetil is safe, well tolerated, and preserves lung function in patients with connective tissue disease-related interstitial lung disease. Chest. 2006;130(1):30-36. Accessed Jul 23, 2020. doi: 10.1378/chest.130.1.30.

12. Dp T, R E, Pj C, et al. Cyclophosphamide versus placebo in scleroderma lung disease. The New England journal of medicine Web site. https://pubmed-ncbi-nlm-nihgov.libproxy.temple.edu/16790698/?dopt=Abstract. Updated 2006. Accessed Jul 21, 2020.

13. Steen VD, Medsger TA. Case-control study of corticosteroids and other drugs that either precipitate or protect from the development of scleroderma renal crisis. Arthritis Rheum. 1998;41(9):1613-1619. Accessed Jul 23, 2020. doi: 10.1002/1529-0131(199809)41:9<1613::AID-ART11>3.0.C0;2-O. 
14. Trang G, Trang G, Steele R, et al. Corticosteroids and the risk of scleroderma renal crisis: A systematic review. Rheumatol Int. 2012;32(3):645-653. https://www.ncbi.nlm.nih.gov/pubmed/21132302. doi: 10.1007/s00296-010-1697-6.

15. Y Y, H T, Y K, et al. Multidimensional improvement in connective tissue disease-associated interstitial lung disease: Two courses of pulse dose methylprednisolone followed by low-dose prednisone and tacrolimus. Respirology (Carlton, Vic.) Web site. https://pubmed-ncbi-nlm-nihgov.libproxy.temple.edu/30011421/. Updated 2018. Accessed Jul 21, 2020.

16. Graham BL, Steenbruggen I, Miller MR, et al. Standardization of spirometry 2019 update. an official american thoracic society and european respiratory society technical statement. Am J Respir Crit Care Med. 2019;200(8):e70-e88. https://doi.org/10.1164/rccm.201908-1590ST. doi: 10.1164/rccm.201908-1590ST.

17. Pharmacodynamics of glucocorticoids. Clin Exp Rheumatol Web site. https://www.clinexprheumatol.org/abstract.asp?a=5275. Accessed Aug 19, 2020.

18. Hanada M, Sakamoto N, Ishimatsu Y, et al. Effect of long-term treatment with corticosteroids on skeletal muscle strength, functional exercise capacity and health status in patients with interstitial lung disease. Respirology. 2016;21(6):1088-1093. https://onlinelibrary-wileycom.libproxy.temple.edu/doi/full/10.1111/resp.12807. Accessed Aug 19, 2020. doi: 10.1111/resp.12807.

\section{Figures}

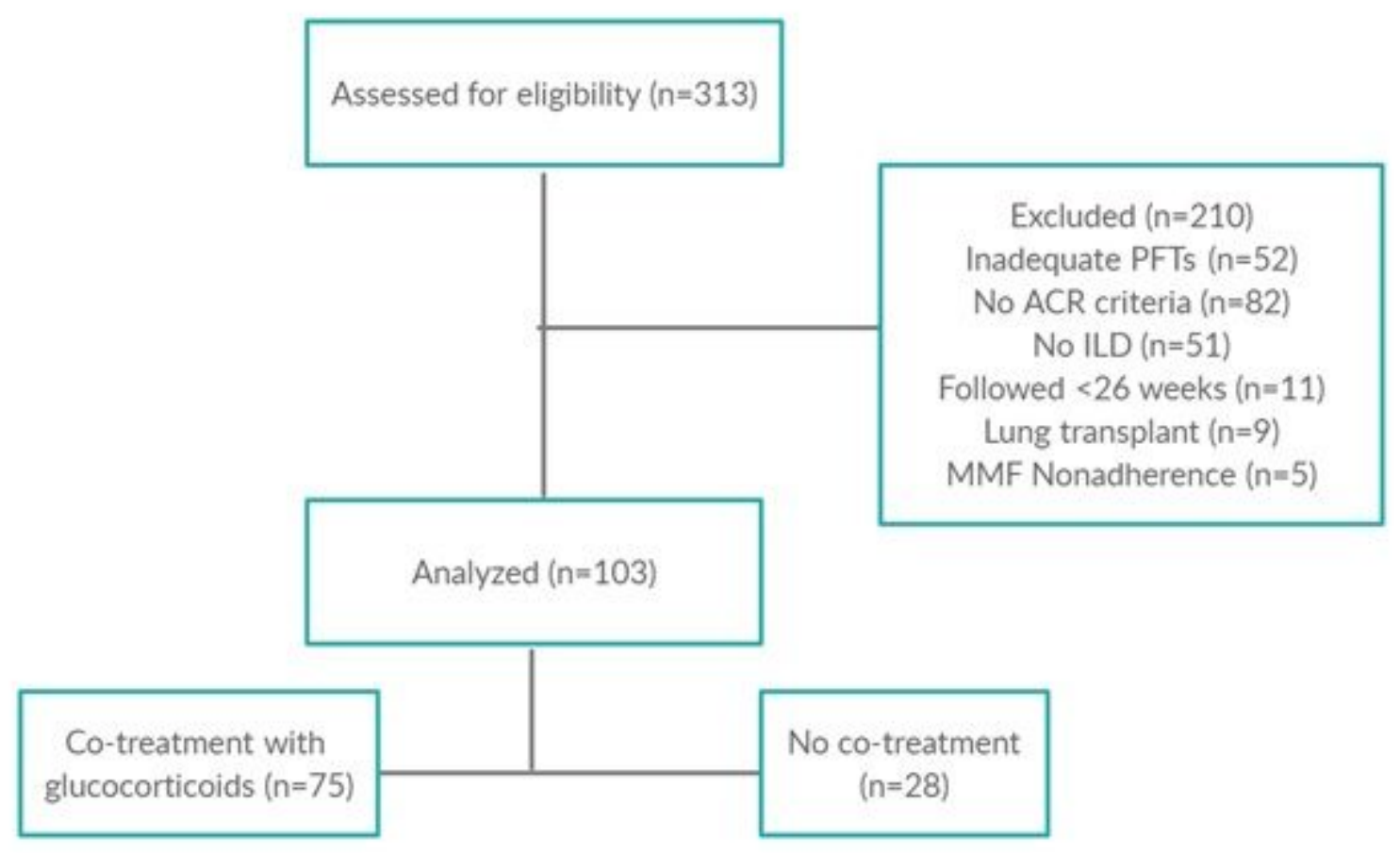

\section{Figure 1}


Inclusion and Exclusion Criteria

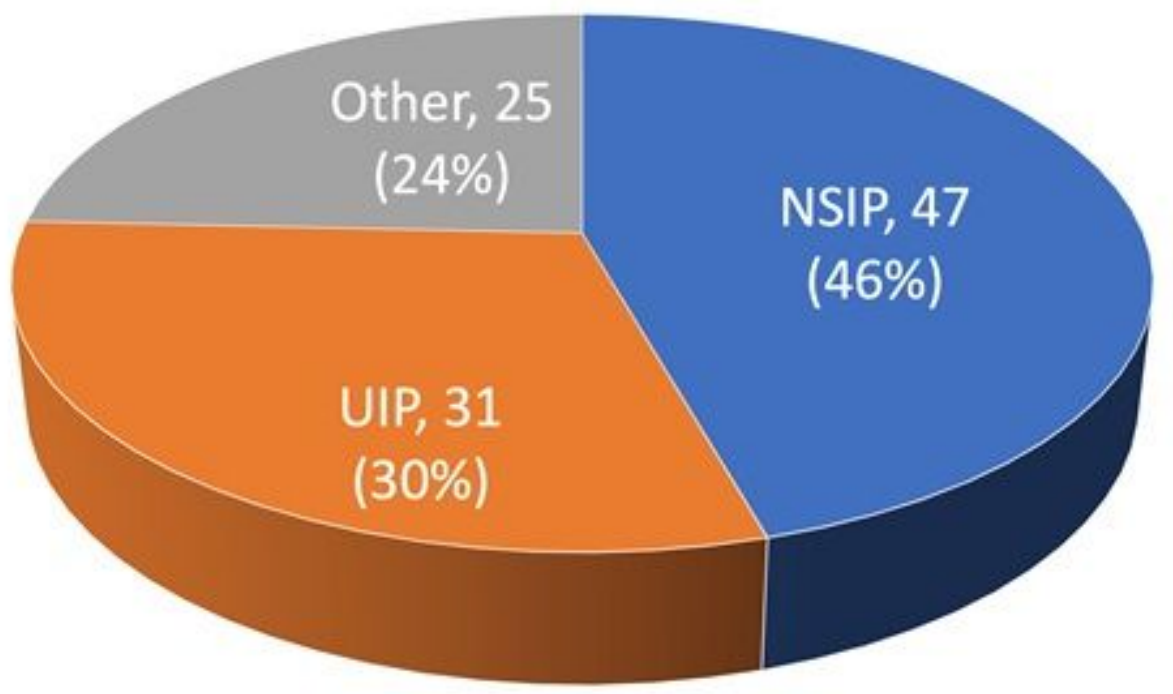

Figure 2

Pattern of ILD by HRCT or Histology in CTD-ILD Patients on MMF. Legend: Interstitial Lung Disease (ILD), High-Resolution Computed Tomography (HRCT), Connective Tissue Disease Interstitial Lung Disease (CTD-ILD), Mycophenolate Mofetil (MMF), Usual Interstitial Pneumonia (UIP), Non-Specific Interstitial Pneumonia (NSIP), Other ILD Pattern (Other)

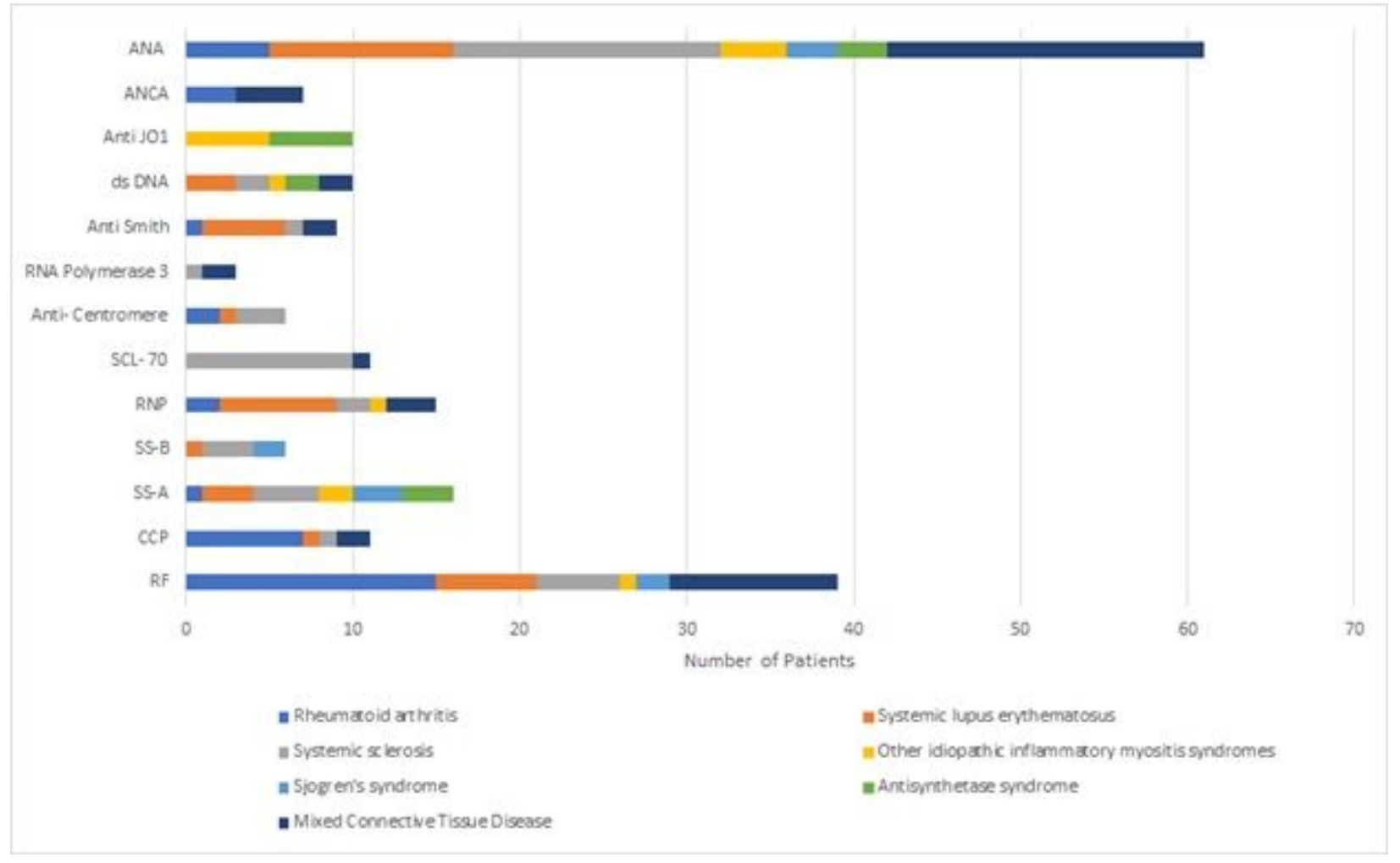

Figure 3 
Baseline Autoantibodies in CTD-ILD Patients on MMF. Legend: Connective Tissue Disease Interstitial Lung Disease (CTD-ILD), Mycophenolate Mofetil (MMF), Antinuclear Antibody (ANA) $\geq 1: 320$ (ANA), antiRNP antibody (RNP), Anti-centromere antibody (Anti-centromere), Anti-Double-Stranded DNA antibody (dsDNA), Sjögren's Syndrome-Related-Antigen A/ Anti-Rho (SS-A), Sjögren's Syndrome-Related-Antigen B/ Anti-La (SS-B), Anti-Smith Antibody (Anti-Smith), Topoisomerase-1 (SCL-70), Antihistidyl transfer-RNA [tRNA] synthetase (Anti-Jo 1), Anti-Citric Citrullinated Peptide (Anti-CCP), Rheumatoid Factor (RF), AntiSmith Antibody (Anti-Smith), Anti-RNA Polymerase 3 Antibody (RNA Polymerase 3), Antineutrophil Cytoplasmic Antibodies (ANCA) 